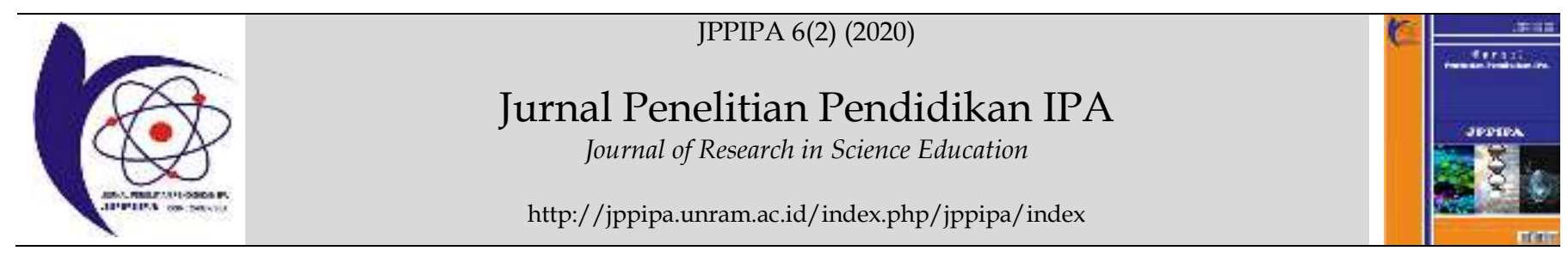

\title{
Improving Critical Thinking Skill of Junior High School Students through Science Process Skills Based Learning
}

\author{
Diego Pradana ${ }^{1 *}$, Mohamad Nur ${ }^{1}$, Nadi Suprapto ${ }^{1,2}$ \\ 1Science Education Study Program Postgraduate, State University of Surabaya, Indonesia \\ ${ }^{2}$ Physics Education Study Program, State University of Surabaya, Indonesia
}

DOI: $\underline{10.29303 / \text { ippipa.v6i2.428 }}$

\section{Article Info}

Received : April 20th 2020

Revised : June $5^{\text {th }}, 2020$

Accepted : June 13, 2020

\begin{abstract}
This study aimed to investigate impact the science process skill-based learning on critical thinking skills of Junior High School students. Subjects were eighth grade students of Rengel Junior High School 1 that were selected by purposive random sampling. Measurement data by means of science process skills test and critical thinking skill test was analyzed by using inferential statistical one-tailed t-test and linear regression. The results showed that implementation of science process skill-based learning was effective to improve the critical thinking skill of Junior High School student.
\end{abstract}

Keywords: Critical Thinking skill; Science Process Skill; Junior High School.

Citation: Pradana, D., Nur, M., \& Suprapto, N. (2020). Improving Critical Thinking Skill of Junior High School Students through Science Process Skills Based Learning. Jurnal Penelitian Pendidikan IPA (JPPIPA), 6(2), 166-172. doi: https://doi.org/10.29303/jppipa.v6i2.428

\section{Introduction}

Science learning is an instruction that aims to direct students in developing epistemological understanding of science knowledge and the nature of science (Khalick, 2012). Science is essentially not only as a mastery of the concept of understanding nature. Science is more a set of processes that used to build, expand, and improve knowledge (NRC, 2012). The science of learning process emphasizes providing direct learning experiences so that students actively construct understanding of natural phenomena, concepts, and principles of science (Hammond, et al., 2019) through the development of science process skills (Ambross, et al., 2014).

Science process skills are special skills to simplify the way of learning science and instill students' scientific skills (Karamustafaoğlu, 2011). Science process skills defined as the adaptation of the skills that used by scientists for composing knowledge, thinking of problems and making conclusions (Karsli \& Alipasa,
2014). The development of science process skills is closely related to student competencies in achieving learning goals (Hilman, 2014). The implementation of science process skills-based learning designed is expected to lead students to develop the skills needed in the $21^{\text {st }}$ century (Turiman, et al., 2012) to investigate nature, solve problems and make decisions (Ridho et al., 2020)

One of the $21^{\text {st }}$ century skills is the critical thinking skill (Alismail \& McGuire, 2015). Critical thinking is a skill or process that enables students to gain new knowledge through the process of problem solving and collaboration (Walker \& Finney, 2006). The critical thinking skill focuses more on the learning process rather than just the acquisition of knowledge. The critical thinking skill involves activities, such as interpreting, analyzing, evaluating, concluding, explaining the results of his thinking, and how to make decisions and apply new knowledge (Facione, 2011). Based on these reasons the development of students' 
critical thinking skills is the main goal in the science learning process (Zoller, et al., 2000).

Critical thinking as one of the skills that are widely studied in junior high school (Arslan, 2012). Critical thinking is used as an ability that plays an important role and is widely discussed in the world of education in the last two decades (Demir, et al., 2011). The critical thinking skill is considered important in the learning process because it provides opportunities for students to learn through discovery. Students are required to have critical thinking skills in order to solve problems in daily life, become reflective practitioners, and make decisions based on available evidence (Pieterse, et al., 2016). Students who have critical thinking skills are expected to be able to understand and participate in solving various problems in life and technology in accordance with the demands of the times.

The critical thinking skill of Indonesian students can be categorized to be low. Based on the results of the study on the Program for International Students Assesment (PISA) in 2015 showed that the achievement of Indonesia students in the dimension of scientific process or skills, concepts and content, context or application in the field of science is ranked at 64 from 65 countries (OECD, 2018). The low achievement of Indonesian junior high school students in the PISA test is due to something. If assumed all human beings are created equal, the interpretation of this outcome is only one, namely: that we teach in schools different from the demands of the times (Rahayu, 2016). Learning in schools mostly only makes students focus on mastering the concept of science regardless of the process of discovery and its relevance and application in daily life. These conditions make the progress of students ' thinking processes limited, resulting in low student critical thinking skills (Heong, et al., 2014).

The results of Nuryanti research (2018) through the use of test instruments developed by Ennis (2011), also showed that the ability to think critically of junior high school students was still low. The results of students critical thinking skills that were categorized correctly in the aspect of analyzing explanations were only $27.6 \%$, making decisions $27.6 \%$, inference $6.1 \%$, making definitions $24.1 \%$, and making logical predictions $6.8 \%$. Other studies conducted by Nugraha, et al. (2017) shows that student's critical thinking skills are influenced by science process skills by $41.5 \%$. Based on these results the low ability of students critical thinking will correlate positively with the untrained of student's science process skills. Atkamis \& Nilgun (2010) stated that low student science process skills also followed low critical thinking skills.

Based on the results of preliminary studies in several junior high schools in Surabaya using a test instrument developed by Kazeni (2005) shows that the science process skills of junior high school students are still relatively low. The results of student's science process skills that were categorized correctly in the aspect of identifying and controlling variables were only $10.3 \%$, stating hypotheses $12.5 \%$, operational definitions $14.6 \%$, graphing and interpreting data $16.7 \%$, and experimental design $6.8 \%$.

In an effort to overcome these problems, it is necessary to synergize teaching, learning and thinking by critical thinking and problem-solving through scientific process in science learning (Suprapto, 2016). Through the science process skill based learning is expected to improve students' critical thinking skills. The development of science process skills enables students to acquire the skills needed to solve problems through scientific methods (Kazeni, 2005). Science process skill based learning by using adapted syntax are developed by Khaeruddin (2017): (i) identification of ideas (the teacher asks questions or issues), (ii) collaboration (the teacher engages students in study groups in order to solve a problem or task together to produce a product.), (iii) authentic investigation: science processes skills (the teacher guides and does the analysis, interpretation and inference based on data from group investigation), (iv) class discussion and presentation (the teacher gives students a chance to interpret and infer related to the data results of the group investigation through discussion). This syntax is specifically designed to practice the science process skills to improve critical thinking skills

During scientific activities, science process skills are very closely related to students' cognitive domains such as critical thinking skills and problem-solving skills (Özgelen, 2012). The idea is based on the constructivist paradigm where during the learning process students are emphasized to build their own knowledge through active involvement in the learning process (Vaithyanathan, \& Sivakumar, 2013). Another theory that supports is the social learning theory. Social learning theory emphasizes observation and participation with social interaction as a basis for cognitive development (Arends, 2012).

Based on the explanation above, it is important to do further research to the critical thinking skill of Junior High School students through science process skills based learning. The chase is expected to provide a meaningful learning experience for students especially on the aspect of critical thinking skills.

\section{Method}

This pre-experimental quantitative study that used a one-group pretest-posttest design (Fraenkel, et al., 2012). This method used to investigate impact the 
science process skill-based learning on critical thinking skills. The population in this study was 221 students of Rengel Junior High School one-year lesson 2019/2020. This study was applied to a single group with no comparative group or control group selected in purposive random sampling. The classes used are VIII (B). Learning is done as many as 3 meetings, plus 1 meeting for the pretest, and 1 meeting for the posttest.

The instruments in this study include: 1) Instruments of treatment: syllabus, learning implementation plan, and student worksheets, and student teaching books 2) Measuring instruments are: the spreadsheet of learning reliability, the written test of science process skills, and tests of critical thinking skill. Data collection is done by 1) observation of the implementation of learning model and 2) pretestposttest of science process skills and critical thinking ability. The implementation value of learning is adjusted to the criteria in Table 1 below.

Table 1: Learning Implementation Criteria Level

\begin{tabular}{ll}
\hline Score & Implementation Category \\
\hline $3.25<$ score $\leq 4.00$ & Very effective \\
$2.50<$ score $\leq 3.25$ & Effective \\
$3.75<$ score $\leq 2.50$ & Quite effective \\
$1.00<$ score $\leq 1.75$ & Not effective \\
\hline
\end{tabular}

Improved test result science process skills and critical thinking ability from pretests to posttest calculated with normalized gain (n-Gain) score. Data on improving science process skills and critical thinking skills from pretest to posttest were analyzed using one-tailed t-test through the SPSS (Statistical Package for the Social Sciences) program with criteria if the value of $p$ value (sig./2) $>a(=0.05)$ : there is no difference in test results before and after treatment $\left(\mathrm{H}_{0}\right)$, and if the $\mathrm{p}$ value (sig./2) $<a(=0.05)$ then after the treatment test results were significantly higher than before treatment $\left(\mathrm{H}_{1}\right)$.

The use of one-tailed t-test because the treatment instrument is designed logically and consistently in order to improve critical thinking skills so that the posttest results are believed to be higher than the results of the pretest. The relationship between science process skills and critical thinking skills is calculated using linear regression analysis through the SPSS program.

\section{Result and Discussion}

\section{A. Description of Learning Implementation}

The average results of observations of the implementation of the learning process in the class are presented in Table 2 below.
Table 2: Results of Learning Process Implementation

\begin{tabular}{ll}
\hline Meeting & Achievement Score \\
\hline First & 3.50 \\
Second & 3.75 \\
Third & 3.75 \\
Mean & 3.66
\end{tabular}

Table 2 shows that the average score of learning accomplishment reached 3.66 are included in the very effective category.

\section{B. Description of Student Science Process Skill}

The assessment of science process skills uses six essay questions that are adjusted to each indicator. Science process skills indicators are selected from a number of basic process skills and integrated process skills that enable the improvement of critical thinking skills. The level of students' science process skills for each indicator is shown in Table 3 below.

Table 3: Test Results of Science Process Skill

\begin{tabular}{llll}
\hline \multirow{2}{*}{ Indicator } & \multicolumn{2}{l}{ Score } & Gain \\
\cline { 2 - 3 } & Pretest & Posttest & score \\
\hline Formulating hypotheses & 37.78 & 91.11 & \\
Identifying operational & 18.33 & 75.83 & \\
variables & 17.78 & 87.78 & 0.71 \\
Creating tables & 16.67 & 73.33 & (High) \\
Making a chart & 11.11 & 95.56 & \\
Interpreting graph & 16.67 & 78.33 & \\
Making conclusion & & & \\
\hline
\end{tabular}

Table 3 shows that the average level science process skills of students after treatment were higher for each indicator. The data shows that there is an increase in students' science process skills after treatment.

\section{Description of Student Critical Thinking Skill}

The assessment of critical thinking skills uses three essay questions that are adjusted to each indicator. Indicators of critical thinking ability are selected from several indicators developed by Facione (2011) which are adjusted to the high level of cognitive and thinking ability level of junior high school students. The level of student critical thinking skills for each indicator is shown in Table 4 below.

Table 4: Test Results of Critical Thinking Skill

\begin{tabular}{lrrl}
\hline \multirow{2}{*}{ Indicator } & \multicolumn{2}{c}{ Score } & Gain \\
\cline { 2 - 3 } & Pretest & Posttest & score \\
\hline Interpretation & 31.67 & 85.00 & \\
Analysis & 36.67 & 83.33 & 0.72 \\
Inference & 26.67 & 88.33 & (High) \\
\hline
\end{tabular}

Table 4 shows that the average level thinking skills of the students after the treatment were higher for each indicator. The data showed that there was an 
increase of students' critical thinking skill after treatment.

\section{Inferential Analysis of Science Process Skill and Critical Thinking Skill}

Analysis of the results of science process skills and critical thinking skills were statistically analyzed using t-test. $\mathrm{T}$ test results of pretest-posttest data on science process skills and students' critical thinking skills are shown in Table 5.

Table 5: Analysis Results of Pretest-Posttest

\begin{tabular}{lll}
\hline Variable & & Sig. \\
\hline T-test & Science process skill & 0.00 \\
one tailed & Critical thinking skill & 0.00 \\
\hline
\end{tabular}

Table 5 shows that the significance value in the T-test of the science process skills is $0.00<0.05$ and the critical thinking skills is $0.00<0.05$. Based on the significance value it can be concluded that after the treatment test results of science process skill and critical thinking skill were significantly higher than before treatment.

Analysis of the relationship between science process skill and critical thinking skill is performed using linear regression. The result of the analysis is as shown in Table 6 below.

Table 6: Analysis regression of relationship

\begin{tabular}{lll}
\hline Model (constant) & $\begin{array}{l}\text { Regression } \\
\text { Coefficient }\end{array}$ & Sig. \\
\hline Science process skills & 0.043 & 0.00 \\
\hline
\end{tabular}

Table 6 shows that there is a relationship between critical thinking skill and science process skill. The result shows that even scores of science process skill change, it can be estimated that score of critical thinking skill also changes at 0.043 in the same direction. Based on the results it is also known that the value of sig is $0.00<0.05$, so it can be concluded that the science process skills significantly influence the critical thinking skill.

The implementation of science learning based on science process skills has proven to be effective in improving the critical thinking skills of junior high school students. This statement can be proven by the difference in the ability to think critically based on the gain score before and after treatment by the science process based on learning skills still in the high category. This result is supported by analysis using ttest which is known that after the treatment test results of critical thinking skills were significantly higher than before treatment.
An increasing ability of students' critical thinking after going through science-based skill learning processes indicated the constructivism learning theory is confirmed that it can improve critical thinking skills. In constructivist theory, Dagar \& Yadav (2016) assumes that students must construct their own knowledge individually and collectively trough assimilation, accommodation, and equilibration. Each student has a conception and skill to construct knowledge in order to solve real problems. Students are given the opportunity to interact with the environment to be able to practice their ability to think related to the concept of information obtained. If students do not have experiences in the field, the teacher is responsible for guiding students' activities, behavior modeling, and providing examples through group discussions to be meaningful communication about the subject matter. It also indicates the social learning theory supporting learning process. This theory emphasizes the cognitive component of mind, understanding and evaluation (Nur, 1998). Vygotsky in Woolfolk, et al. (2011), states that social interaction is an important thing in learning because it functions high-level mental such as reasoning, comprehension and critical thinking that comes from social interaction, which it is further internalized by individuals. In the interaction process students are given scaffolding assistance at the beginning of activities related to complex tasks, difficult, but realistic (top down instruction) so students are able to think in the proximal zone to achieve highlevel cognitive functions (Wass, et al., 2011).

In this study, constructivist theory and social learning theory are organized in learning activities as models that support theories in improving critical thinking skills. Each learning phase of students is required to actively develop their thinking skills either individually or through social interaction. The relationship can be explained as follows.

(1) Identification of ideas: this stage students are required to be able to express their views by giving arguments to the problems given by the teacher. Students will apply the ability to analyze and interpret the observed phenomena because each student has the conception and skills to build their knowledge in order to solve real problems (Lunenburg, 2011).

(2) Collaboration: this stage students are involved in some learning groups where each group is learned in a working group with student worksheets through interaction with friends. Students have the opportunity to discuss, take responsibility, hold opinions or 
interpret, and become critical thinkers. Collaborative learning emphasizes the importance of students' relationships with others in developing critical thinking skills (Lai, ER, 2011).

(3) Authentic investigation (science processes skills): this stage students are involved in groups in doing student worksheets oriented to science process skills. Students conduct analysis, interpretation and inference based on authentic investigation data, so students have the opportunity to develop thinking skills through the approach of science process skills and scientific methods. Özgelen (2012) explains that learning science should be carried out to develop thinking skills through a series of scientific methods including activities such as formulating problems, designing experiments, collecting data, analyzing findings, concluding and communicating. Solihah (2016) states that during the investigation activities science process skills and scientific methods will be the driving force of students' thinking abilities in finding facts and concepts.

4) Class discussion and presentation: this stage students are conducted experiments as listed on student worksheets in groups, presented the results of the experiments / observations, and gave a rational explanation to enhance the answer of other groups. Students in this case are required to make mutual interpretations and inferences related to group investigation results. According to Maesek \& Sulaiman (2012) Processes such as discussion, debating, sharing, and teaching one another, creates a platform for students to experience an environment that is conducive for critical thinking to growth.

Several syntaxes of the above learning activities as a whole are intended to improve students' critical thinking skills by focusing on student involvement in learning and understanding that critical thinking is a construction and evaluating reasoning (metacognition), not showing a correct answer or just an opinion. In addition, in the learning process, students are given the opportunity to take a role in collaboration, solve problems and make decisions. Magno (2010) states that, metacognitive knowledge will bridge students in controlling their way of thinking to complete difficult tasks such as interpretation, inference, analysis or evaluation of arguments as a thought process.

The high involvement of students in practicing metacognition of critical thinking, because during the learning process based on science process students can identify as many as possible the issues that are relevant to the material, so they can pick one issue and formulate it in hypothetical form (temporary answer to the question), besides that the students did the interpretation and inference related to the result of the data from the investigation group through the approach of science process skills and scientific methods. So, there was an increase in skills in interpreting and inferring students based on data and developing self-confidence. Thus, the improvement of critical thinking skills is significantly related to the development of students' science process skills.

According to Özgelen (2012), the development of science process skills enables students to construct and solve problems and think critically. This possibility can occur because the components of critical thinking are mostly components of science process skills such as designing experiments, testing hypotheses, stating hypothesis, predicting, inferring, classifying, measuring, and observing (Hassard, J., 2005). It is supported by the result research of Irwanto et al. (2019) that states that the critical thinking skills can be developed through the development of science process skills.

\section{Conclusion}

Based on the results of analysis and discussion showed that implementation of science process skillbased learning was effective to improve the critical thinking skill of Junior High School student. This result carried as the relationship between science process skills and critical thinking skill. In other words, critical thinking skill can be developed through the science process skill-based learning.

\section{References}

Alismail, H. A., \& McGuire P. (2015). 21 ${ }^{\text {st }}$ Century Standarts and Curriculum: Current Research and Practice. Journal of Education and Practice, 6 (6), 150-154.

Ambross J., Les, M., \& Sylvan, B. 2014. The Implementation and Development of Science Process Skills in the Natural Sciences: A Case Study of Teachers' Perceptions. Journal Africa Education Review, 11(3), 459-474. doi: https://doi.org/10.1080/18146627.2014.934998

Arends, R. 2012. Learning to Teach Edisi Kesembilan Buku 1. Jakarta: Salemba Humanika.

Arslan, S. (2012). The Influence of Environmental Educational on Critical Thinking And Environmental Attitude, Procedia Social and Behavioral Science, 1 (55), 902-909. doi: https://doi.org/10.1016/j.sbspro.2012.09.579

Atkamis, H., \& Nilgun, Y. (2010). Determination of the Science Process Skills and Critical Thinking Skill Levels. Procedia Social and Behavioral Science, 2 
(2010), 3282-3288. doi: https://doi.org/10.1016/j.sbspro.2010.03.502

Dagar, V., \& Yadav, V. (2016). Contuctivism: a paradigm for teaching and learning. Art and social science journal, 7(4), 1-4. doi:10.4172/21516200.1000200

Demir, M., Hasan, B., Sinem, T., \& Mehmet, A. D. (2011). Quadruple Thinking Critical Thinking. Procedia Social and Behavioral Science, 1 (2011), 545551. doi: https://doi.org/10.1016/j.sbspro.2011.02.065

Ennis, R, H. (2011). The Nature of Critical Thinking: an Outline of Critical Thinking Disposition and Abilities. Last revisied emertius professor: University Illions.

Facione, P. A.. (2011). Critical Thinking: What It Is and Why It Counts, Retrieved from http://jmorante@insightassessment.com

Fraenkel, J. R., Wallen, N. E., \& Hyun, H. H. (2012). How to Design and Evaluate Research in Education (Vol. 7). New York: McGraw-Hill.

Hammond, L. D., Lisa, F., Chana, C. H., Brigid, B., \& David, O. (2020). Implication for Educational Practice of the Science Learning and Development. Applied Developmental Science, 24(2), 97-140. doi: https://doi.org/10.1080/10888691.2018.1537791

Hassard, J. 2005. The Art Teaching Science. New York: Oxford University Press.

Heong, Y.M., Yunos, J.M., Othman, W., Hassan, R., Kiong, T.T. \& Mohamad, M.M. (2014). Disparity of Learning Style and Higher Order Thinking Skills among Technical Students. Procedia-Social and Behavioral Sciences, 204: 143-152. https://doi.org/10.1016/j.sbspro.2015.08.127

Hilman. (2014). Pengaruh Pembelajaran Inkuiri Terbimbing dengan Mind Map terhadap Keterampilan Proses Sains dan Hasil Belajar IPA. Jurnal Pendidikan Sains, 2 (4): 221-229.

Irwanto, Anip, D. S., \& Eli, R. (2019). Using InquiryBased Laboratory Instruction to Improve Critical Thinking and Scientific Process Skill Among Preservice Elementary Teachers. Eurasian Journal of Educational Research, 80 (2019), 151-170. doi: 10.14689/ejer.2019.80.8

Karamustafaoğlu, S. (2011). Improving the Science Process Skills Ability of Science Student Teachers Using I Diagrams. International Journal of Physics $\mathcal{E}$ Chemistry Education, 3(1), 26-38. Retrieved from http://www.ijpce.org/index.php/IJPCE/article $\angle$ view/99

Karsli, A., \& Alipasa, A. (2014). Developing a Laboratory Activity by Using 5E Learning Model on Student Learning of Factor Affecting the Reaction Rate and Improving Scientific Process
Skill. Social and Behavioral Sciences, 143 (2014), 663-668.

doi:

https://doi.org/10.1016/j.sbspro.2014.07.460

Kazeni, M.M.M. (2005). Development and Validation of a Test Integrated Science Process Skills for The Further Education and Training Learners. (Unpublished master thesis), Pretoria university of south Africa

Khaeruddin. (2017). Model Pembelajaran Fisika Berbasis Keterampilan Proses Sains (Model FBKPS). Gowa: Pustaka Almaida

Khalick, F.A. (2012). Teaching with and About Nature of Science, and Science Teacher Knowledge Domains. Science E Education, 22 (9), 2087-2107. doi: https://doi.org/10.1007/s11191-012-9520-2

Lai, E. R. (2011) Critical Thinking: A Review Research Report. United Kingdom: Pearson Always Learning.

Lunenburg, F.C. (2011). Critical thinking and constructivism techniques for improving student achievement. In National Forum of Teacher Education Journal. 21(3), 1-9.

Maesek, A., \& Sulaiman, Y., (2012). The Impact of Instructional Methods on Critical Thinking: A Comparison of Problem-Based Learning and Conventional Approach in Engineering Education. International Scholarly Research Network Education, 1(2012), 1-6. doi: https://doi.org/10.5402/2012/759241

Magno, C. (2010). The role of Metacognitive Skill in Developing Critical Thinking. Metacognition and Learning, 5(2010), 137-156.

National Research Council. (2012). A Frame Work for K12 Science Education Practices, Crosscutting Concept, and Core Ideas. Washington DC: National Academy Press.

Nugraha, A. J., Hardi, S., \& Endang, S. (2017). Kemampuan Berpikir Kritis Ditinjau Dari Keterampilan Proses Sains dan Motivasi Belajar Melalui Model PBL. Journal of Primary Educating, 6 (1): 35-43. doi: 10.15294/jpe.v6i1.14511

Nur, M. (1998). Proses Belajar Mengajar dengan Pendekatan Keterampilan Proses. Surabaya: SIC Surabaya.

Nuryanti, L., Siti, Z., \& Markus, D. (2018). Analisis Kemampian Berpikir Kritis Siswa SMP. Jurnal pendidikan, 3 (2), 155-158.

OECD. (2018). PISA 2015 Results in Focus: What 15-yearsolds know and what they can do with what they know. Retrieved from http://www.oecd.org

Özgelen, S. (2012). Students' Science Process Skills within a Cognitive Domain Framework. Eurasia Journal of Mathematics, Science \& Technology Education. 8(4), 283-292. doi: https://doi.org/10.12973/eurasia.2012.846a 
Pieterse, T., Heather, L., \& Hesta, F., (2016). Critical Thinking Ability of 3rd Year Radiography students. Health sa geshodeid; 21 (2016), 381-390

Rahayu, S. (2016). Pengembangan Keterampilan Berpikir Tingkat Tinggi Siswa Melalui Pembelajran Kimia Berkonteks Socioscientific Issues (SSI) Dan Nature of Science (NOS). Paper presented at seminar nasional kimia dan pembelajarannya 2016.

Ridho, S., Ruwiyatun, R., Subali, B., \& Marwoto, P. (2020). Analisis Kemampuan Berpikir Kritis Siswa Pokok Bahasan Klasifikasi Materi dan Perubahannya. Jurnal Penelitian Pendidikan IPA, 6(1), 10-15. doi:https:// doi.org/10.29303/jppipa.v6i1.194

Solihah, R., Agus, A. P., \& Erin, R. G. 2016. Penerapan Pembelajaran Investigasi Kelompok Untuk Meningkatkan Keterampilan Proses Sains Ditinjau Dari Intelligence Quotient Siswa. Jurnal Penelitian Pendidikan IPA (JPPIPA), 2(2), 1-11. doi:https://doi.org/10.29303/jppipa.v2i2.39

Suprapto, N. (2016). What should educational reform in Indonesia look like? Learning from the PISA science scores of East-Asian countries and Singapore. Asia-Pacific Forum on Science Learning and Teaching, 17(2), 1 -21.

Turiman, P., Jizah, O., Adzliana, M. D. \& Kamisah. (2012). Fostering the 21 $1^{\text {st }}$ Century Skill through Scientific Literacy and Science Process Skill. Social and Behavioral Sciences, 59(2012), 110-116. doi:https://doi.org/10.1016/j.sbspro.2012.09.253

Vaithyanathan,V., \& Sivakumar P. (2013. Effectiveness Of Cognitive Constructivist Approach in The Acquisition of Science Process Skills. International Journal of Innovative Research \& Development, 2 (1), 56-64.

Walker, P. \& Finney, N. (2006). Skill Development and Critical Thinking in Higher Education. London: Higher Education Research \& Development Unit,University College.

Wass, R., Toni, H., \& Alison, M. (2011). Scaffolding critical thinking in the zone of proximal development. Teaching in Higher Education, 19 (6), 671-684. doi: https://doi.org/10.1080/07294360.2010.489237

Woolfolk, A. H., \& Hughes, M. M. \& Walkup, V. (2008). Psychology in Education. New York: Pearson.

Zoller, U., Ben-Chaim, D., \& Ron, S. (2000). The Disposition Toward Critical Thinking of High School and University Science Students: An Inter-Intra Isreaeli-Italian Study. International Journal of Science Education, 22(6), 571-582. doi:https://doi.org/10.1080/095006900289679 